\title{
Identification and preliminary characteristics of odour sources in biogas plants processing municipal waste
}

\author{
Marta Wiśniewska ${ }^{1, *}$ Andrzej Kulig ${ }^{1}$, Krystyna Lelicińska-Serafin ${ }^{1}$ \\ ${ }^{1}$ Warsaw University of Technology, Faculty of Building Services, Hydro and Environmental \\ Engineering, 20 Nowowiejska St., 00-653 Warsaw, Poland
}

\begin{abstract}
The paper presents results of local visions at six biogas plants processing municipal waste in Poland. The study objective was the investigation of waste processing technology, as well as the initial identification and characteristics of odour sources. The literature provides scarce information on research on the occurrence of odours in this type of objects. The main components of process gases from biogas plants include ammonia, hydrogen sulphide, and volatile organic compounds. They are not only unpleasant, but also can be harmful to both the environment and people. The main unit operations and processes that make up the technological sequence of biogas plants for municipal waste are: supply and storage of raw waste, preparation of the substrate for fermentation (pre-treatment), main processing (methane fermentation), and stabilisation and storage of the fermented residue. Any irregularities related to running individual processes may contribute to the intensified odour impact of a biogas plant. Local visions permitted the analysis of the technological processes carried out in the plants, as well as the location of odour sources important for further research.
\end{abstract}

\section{Introduction}

Process gases from processing of municipal waste contain numerous organic (volatile fatty acids, aldehydes, ketones, alcohols) and inorganic compounds (hydrogen sulphide, ammonia) [1]. In the case of biological processing of waste in anaerobic conditions, biogas is one of the products. It is flammable gas particularly composed of methane and carbon dioxide. Substances included in the composition of the biogas mixture also contain (in small amounts): hydrogen sulphide, nitrogen, hydrogen, carbon dioxide and gas hydrocarbons [2]. The main components of biogas - methane and carbon dioxide - are odourless gases, but the accompanying compounds have a characteristic unpleasant smell they cause intensive odour emission. Odours are a mixture of different compounds, socalled deodorants. According to [3] they are substances that stimulate the human sense of smell.

\footnotetext{
* Corresponding author: marta.wisniewska.89@,wp.pl
} 
Biogas plants processing municipal waste are investments offering a number of benefits for both the economy and the environment. They are an inherent part of the urban structure. Issues related to waste management are a very important element of sustainable development of cities which is of paramount importance for environmental protection [4]. Biogas installations on the one hand are a part of waste management plants, and on the other hand - a source of energy (due to the transformation of the produced biogas into electric and/or heat energy). The investments correspond well with the assumption of the European Union policy concerning the circular economy [5]. According to the act [6], a renewable energy source is a source of energy covering among others energy obtained from biomass. Biomass is defined among others as a part of municipal waste of plant or animal origin. Due to this, biogas plants processing municipal waste can be included to renewable energy source installations when the substrate for the fermentation process is biodegradable waste from selective collection, and not a fraction separated from a stream of mixed waste. In Poland at the end of 2017, eight plants processing municipal waste functioned using the process of methane fermentation in the biological part, but much more of them will probably be built in the future.

The paper presents effects of local visions at municipal waste treatment plants equipped with biogas plants, and results of pilot research in the premises of one of the installations. The local visions provided the basis for the identification of the source of odours and their preliminary characteristics.

\section{Methodology}

For the purpose of identification of odour sources at biogas plants processing municipal waste, local visions were performed in six mechanical-biological treatment plants (MBT). The preliminary characteristics of odour sources were determined based on research performed by means of the following methodology:

- Olphactometric analyses involving the determination of the ratio of the stream of treated and raw gas (dissolution ratio) $\mathrm{D} / \mathrm{T}$ (Dilution to Threshold) by means of a field olphactometer Nasal Ranger. On the basis of the D/T value, an individual estimate of the odour concentration $\mathrm{Z}_{\mathrm{ITE}}\left[\mathrm{ou} / \mathrm{m}^{3}\right]$ was calculated using the equation:

$$
Z=\left(V_{\text {treated }}+V_{\text {raw }}\right) / V_{\text {raw }}=V_{\text {treated }} / V_{\text {raw }}+1
$$

where:

$\mathrm{Z}$ - dilution ratio [-],

$\mathrm{V}_{\text {treated }}$ - volume of purified gas $\left[\mathrm{m}^{3} / \mathrm{s}\right]$,

$\mathrm{V}_{\text {raw }}$ - volume of raw gas $\left[\mathrm{m}^{3} / \mathrm{s}\right]$.

Two values of the dilution ratio $(Z)$ were calculated, corresponding to the first setting $\mathrm{V}_{\text {treated }} / \mathrm{V}_{\text {raw }}$ at which the odour became perceptible ( $\left.\mathrm{Z}_{\mathrm{YES}}\right)$ and the previous setting $\left(Z_{\mathrm{NO}}\right)$. $Z_{\mathrm{ITE}}$ is the geometric mean of $Z_{\mathrm{YES}}$ and $Z_{\mathrm{NO}}$ values. Odour concentration values $c_{o d}\left[o u / \mathrm{m}^{3}\right]$ were calculated as the geometric mean of the set of $n$ all individual estimates $\left(Z_{\text {ITE }}\right)$ for a given receptor point.

- Measurements of gas concentrations in the air were performed by means of a multi-gas detector MultiRAE (Rae Systems) (volatile organic compounds and ammonia) and gas chromatograph Photovac Voyager (dimethyl sulphide and hydrogen sulphide). 


\section{Biogas plants processing municipal waste in Poland - local visions}

Local visions were performed at mechanical-biological treatment plants processing municipal waste, equipped with biogas installations, located in the six municipalities (no 16). At the remaining two plants - in Gać and Trzebania - no permit for research was obtained. The location of biogas plants processing municipal waste covers west, south, and east Poland. Their detailed distribution is presented in Figure 1.

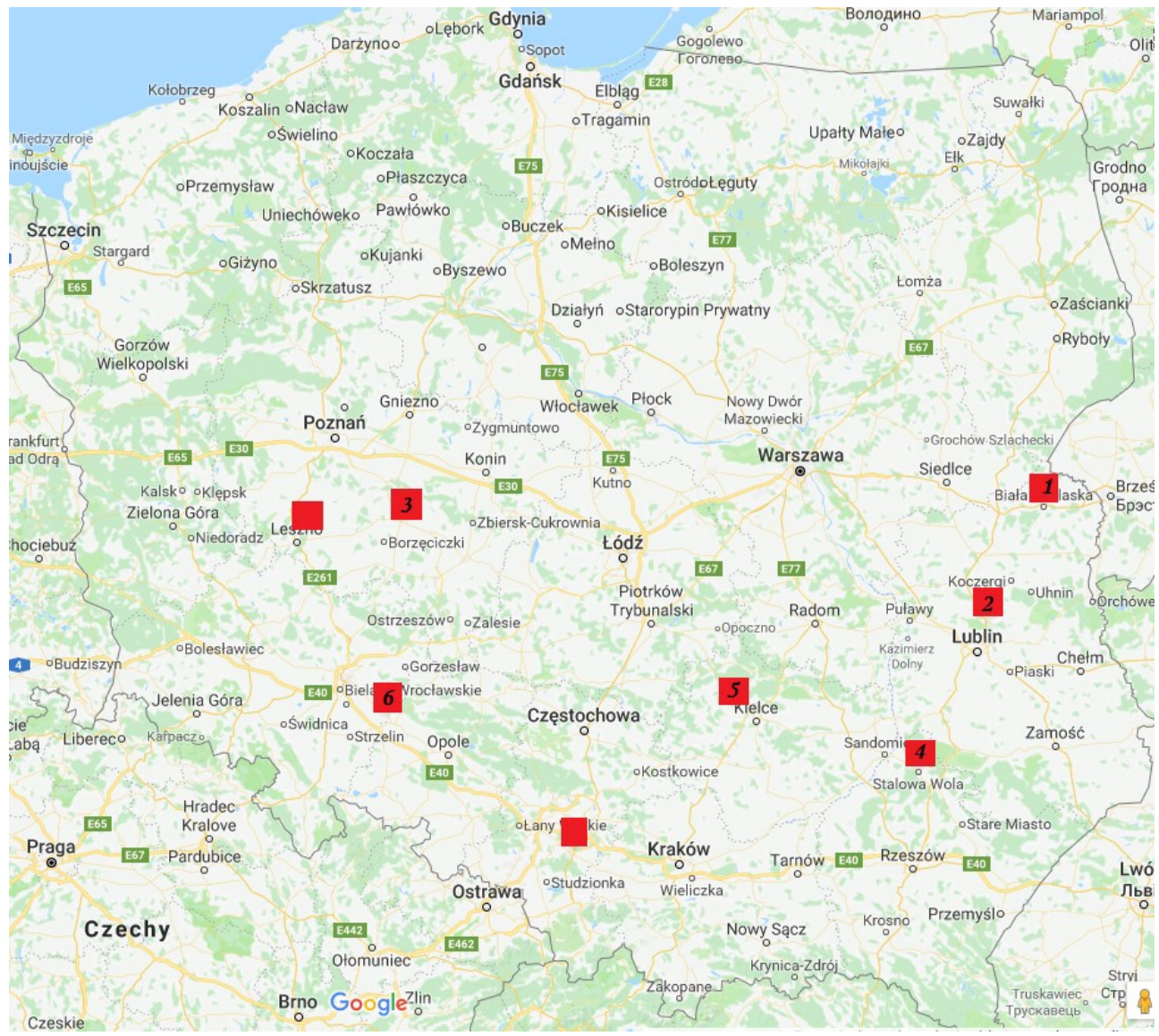

Fig. 1. Location of biogas plants processing municipal waste in Poland (own elaboration based on [7]).

The local visions were carried out from April to July 2018. They provided the basis for the identification of the odour sources, determination of the processing capacity of the plants, type of substrate for fermentation chambers, details of the technological sequence, manner of further procedure with fermented residue and deodorisation methods applied at the plants. 


\section{Study results}

\subsection{Characteristics of biogas plants subject to analysis}

The comparison of all the analysed plants in terms of processing capacities, conditions of the fermentation process, type of substrate for the fermentation process, processing of fermented residue, and the applied methods of process air cleaning of odorants is presented in Table 1.

Table 1. Characteristics of biogas plants processing municipal waste in Poland (own elaboration based on $[8,9,10,11,12,13])$.

\begin{tabular}{|c|c|c|c|c|c|c|}
\hline \multirow{2}{*}{ Parameter } & \multicolumn{6}{|c|}{ Number of biogas plants } \\
\hline & 1 & 2 & 3 & 4 & 5 & 6 \\
\hline $\begin{array}{c}\text { Processing } \\
\text { capacity of the } \\
\text { biogas } \\
\text { installation }\end{array}$ & $\begin{array}{l}\text { approx. } \\
20000 \mathrm{Mg} / \mathrm{a}\end{array}$ & $\begin{array}{c}\text { approx. } \\
20000 \\
\mathrm{Mg} / \mathrm{a}\end{array}$ & $\begin{array}{c}\text { approx. } \\
15000 \\
\mathrm{Mg} / \mathrm{a}\end{array}$ & $\begin{array}{c}\text { approx. } \\
15000 \\
\mathrm{Mg} / \mathrm{a}\end{array}$ & $\begin{array}{l}\text { approx. } \\
30000 \mathrm{Mg} / \mathrm{a}\end{array}$ & $\begin{array}{c}\text { approx. } \\
30000 \\
\mathrm{Mg} / \mathrm{a}\end{array}$ \\
\hline $\begin{array}{l}\text { Type of } \\
\text { methane } \\
\text { fermentation }\end{array}$ & \multicolumn{3}{|c|}{ dry thermophilic } & \multicolumn{3}{|c|}{ dry mesophilic } \\
\hline Substrate & $\begin{array}{l}\text { biodegradable } \\
\text { waste from } \\
\text { selective } \\
\text { collection } \\
\end{array}$ & \multicolumn{5}{|c|}{$\begin{array}{l}\text { biodegradable fraction sorted from mixed municipal waste - } \\
\text { subscreen fraction }\end{array}$} \\
\hline $\begin{array}{l}\text { Fermented } \\
\text { residue } \\
\text { processing }\end{array}$ & \multicolumn{2}{|c|}{$\begin{array}{l}\text { single-step oxygen } \\
\text { stabilisation }\end{array}$} & \multicolumn{4}{|c|}{ two-step oxygen stabilisation } \\
\hline $\begin{array}{l}\text { Deodorisation } \\
\text { method }\end{array}$ & $\begin{array}{c}\text { water } \\
\text { scrubber and } \\
\text { biofilter }\end{array}$ & $\begin{array}{l}\text { chemical } \\
\text { scrubber } \\
\text { and } \\
\text { biofilter }\end{array}$ & biofilter & $\begin{array}{c}\text { chemical } \\
\text { scrubber } \\
\text { and } \\
\text { biofilter }\end{array}$ & $\begin{array}{l}\text { chemical } \\
\text { scrubber, } \\
\text { photocatalytic } \\
\text { oxygenation } \\
\text { and } \\
\text { oxybiofilter }\end{array}$ & $\begin{array}{l}\text { chemical } \\
\text { scrubber } \\
\text { and } \\
\text { biofilter }\end{array}$ \\
\hline
\end{tabular}

The analysis of data included in Table 1 shows that the processing capacity of the fermentation part of the installation oscillates in a range of $15000-30000 \mathrm{Mg} / \mathrm{year}$. Dry fermentation is applied in all of them - thermophilic in three, and mesophilic in the remaining ones.

Biodegradable waste from selective collection constitutes substrate in only one biogas plant. At the remaining plants, a subscreen fraction is separated from the stream of mixed municipal waste. The waste collection system in the area of the service is certainly of great importance for the type of substrate. In the case of Biała Podlaska, biodegradable waste is collected from residents 2-3 times a month. It can constitute an important renewable energy source.

In the case of each installation, fermented residue processing is of aerobic single-step or two-step character. For the two-step process, the second stage occurs in prisms in open area.

At all of the analysed plants, typical deodorisation measures are performed everywhere with the application of biofilters, and in the case of some installations, additionally by means of chemical scrubbers and photocatalytic oxygenation. 


\subsection{Identification of odour sources}

The technological sequence at the analysed plants is very similar. It starts with the unloading hall, where delivered waste is also stored. The mechanical part covers both segregation by means of specialised separators, and manual segregation of separated fractions in sorting cabins. The preparation of the input for fermentation occurs in the designated parts of the hall that also fulfils the function of substrate storage. The fermentation process at each plant lasts for approximately 21 days, and is conducted in a hermitized way. The next stage of the technological sequence is fermented residue dehydration, also carried out in a separate closed hall. Chambers for composting (of green waste) and first stage of oxygen stabilisation (of fermented residue and/or other waste) are usually located in the same place. The second stage of oxygen stabilisation/composting occurs on the designated maturation yard (in open air). Each of the plants is equipped with a biofilter (preceded by water or chemical scrubber), treating process air from technological halls with mechanical and biological processing of waste. Biogas released during the methane fermentation process is subtracted, treated, and stored in a container for the purpose of further energy use.

The local visions performed at the analysed plants permitted the identification of odour sources, particularly including:

- hall of waste admission and storage,

- hall of preliminary processing of waste (mechanical part), including the hall of preparation of substrate for fermentation and its temporary storage,

- mixer of substrate for fermentation chamber,

- hall of fermented residue dehydration and first stage of oxygen stabilisation,

- biogas treatment, storage, and cogeneration station,

- maturation yard (second stage of oxygen stabilisation),

- surface of the biofilter,

- boxes for waste and refuse derived fuel storage.

While analysing the aforementioned sources it is important to emphasise that those cases concern sources of unorganised emission [3]. It is difficult to determine what kind and amounts of compounds are emitted from the specified sources. The literature on the subject provides information on compounds occurring in process gases associated with biogas plants processing municipal waste [14], but particularly data concerning process gases from municipal waste treatment in MBT installations is available, where the biological part is implemented in aerobic conditions. They usually contain: ammonia, volatile organic compounds, and hydrogen sulphide [1].

\subsection{Results of pilot research in the selected plant}

For the purpose of performing preliminary characteristics of the specified odour sources, pilot research was performed at the plant no 3 . It covered the measurement of the concentration of hydrogen sulphide $\left(\mathrm{H}_{2} \mathrm{~S}\right)$, ammonia $\left(\mathrm{NH}_{3}\right)$, total volatile organic compounds (VOC), dimethyl sulphide (DMS), odour (D/T - Dilution to Threshold ), and determination of the odour intensity in a six-degree organoleptic scale (0-5). The study results are presented in Table 2, and the methodology in chapter 2. 
Table 2. Results of pilot research in the scope of preliminary characteristics of sources of deodorants at the selected MBT plant with biogas installation (own elaboration).

\begin{tabular}{|c|c|c|c|c|c|c|c|}
\hline \begin{tabular}{|c|} 
No. of \\
measurement \\
point
\end{tabular} & 1 & 2 & 3 & 4 & 5 & 6 & 7 \\
\hline $\begin{array}{c}\text { Description of } \\
\text { measurement } \\
\text { point }\end{array}$ & $\begin{array}{c}\text { Interior of } \\
\text { the hall of } \\
\text { preliminary } \\
\text { processing of } \\
\text { waste } \\
\text { (mechanical } \\
\text { part) }\end{array}$ & $\begin{array}{l}\text { Interior of the } \\
\text { hall of } \\
\text { preparation of } \\
\text { substrate for } \\
\text { fermentation }\end{array}$ & $\begin{array}{l}\text { Vicinity of the } \\
\text { storage of the } \\
\text { subscreen } \\
\text { fraction } 15-80 \\
\text { mm } \\
\text { (biodegradable) }\end{array}$ & $\begin{array}{l}\text { Vicinity of } \\
\text { mixer and } \\
\text { feeder (with } \\
\text { open doors) } \\
\text { of substrate } \\
\text { for the } \\
\text { fermentation } \\
\text { chamber }\end{array}$ & $\begin{array}{l}\text { Surface of } \\
\text { the open } \\
\text { biofilter }\end{array}$ & $\begin{array}{l}\text { Interior of the } \\
\text { hall of } \\
\text { composting, } \\
\text { oxygen } \\
\text { stabilisation, and } \\
\text { fermented } \\
\text { residue } \\
\text { dehydration (at } \\
\text { the outlet from } \\
\text { the dehydrating } \\
\text { press) }\end{array}$ & \begin{tabular}{|} 
Container for \\
leachate \\
from the \\
dehydrating \\
press
\end{tabular} \\
\hline $\begin{array}{c}\text { Odour } \\
\text { intensity [-] }\end{array}$ & 2 & 4 & 5 & 5 & 1 & 5 & 5 \\
\hline $\mathrm{D} / \mathrm{T}[-]$ & 4,4 & 60,60 & 300,300 & $>500,>500$ & 4,4 & 400,400 & 500,500 \\
\hline $\mathrm{c}_{\mathrm{od}}\left[\mathrm{ou} / \mathrm{m}^{3}\right]$ & 6 & 78 & 347 & 549 & 6 & 448 & 549 \\
\hline VOC [ppb] & 20 & 200 & 2500 & 9000 & 650 & 1300 & 2500 \\
\hline $\mathrm{NH}_{3}[\mathrm{ppm}]$ & $<1$ & $<1$ & $<1$ & 33 & 13 & 22 & 17 \\
\hline $\mathrm{H}_{2} \mathrm{~S}[\mathrm{ppm}]$ & $<0.001$ & $<0.001$ & $<0.001$ & 0.481 & 0.799 & $<0.001$ & 1.421 \\
\hline DMS [ppm] & $<0.001$ & $<0.001$ & 0.406 & 0.151 & $<0.001$ & 0.360 & 0.563 \\
\hline
\end{tabular}

The analysis of results included in Table 2. shows that the highest concentrations of odour and its intensity were recorded with open doors of a mixer of substrate for fermentation chamber, in the fermented residue dehydration hall, and at the container for leachate from the process, as well as in the vicinity of the storage of the subscreen fraction $15-80 \mathrm{~mm}$ (biodegradable). The highest odour concentrations were accompanied by the highest concentrations of volatile organic compounds and ammonia (except for the vicinity of the storage of the subscreen fraction). The highest concentration of sulphur compounds in the air were recorded in the vicinity of the container for leachate from the fermented residue filtering press.

Literature data shows that for hydrogen sulphide, the odour threshold, i.e. the lowest concentration at which human sense of smell recognises a given odour, is $0.0081 \mathrm{ppm}$ $\left(0.0123 \mathrm{mg} / \mathrm{m}^{3}\right)$, for ammonia $-5.2 \mathrm{ppm}\left(3.9 \mathrm{mg} / \mathrm{m}^{3}\right)[15,16]$, and for dimethyl sulphide $0.001 \mathrm{ppm}\left(0.0025 \mathrm{mg} / \mathrm{m}^{3}\right)$ [17]. The data is reflected in observations of the measurement points and in the obtained values of concentrations of compounds.

Results obtained from the measurement point in the form of a biofilter (from its surface) most probably suggest its reduced efficiency and need for the replacement of its filterbed.

\section{Summary and conclusions}

Biogas plants processing municipal waste constitute an important element of urban infrastructure, offering benefits both for the natural environment and the economy. An increase in the awareness of residents in terms of the importance and justification of municipal waste selective collection, including biodegradable fractions, as well as changing requirements in the scope [18], can contribute to an increase in the importance of such plants. Due to the modification of substrate for the fermentation process (to biodegradable fractions from selective collection), the plants will be able to be recognised as a renewable energy source. 
The paper presents effects of local visions at six MBT plants processing part of biodegradable fractions of municipal waste in biogas installations. They permitted the identification of odour sources. The methodology applied in the pilot research in one of the installations was developed based on own experience and literature data.

The research showed significant substantial correlations particularly between the concentration and intensity of odour and the concentration of volatile organic compounds and ammonia in the air/process gases. The highest concentrations of odorants were observed in the vicinity of devices related to the preparation of the substrate for fermentation and fermented residue processing.

Further research should be conducted at all the plants specified in the paper for the purpose of determination of the correlations and factors determining the variability of the concentration of deodorants and odour in the air.

Research partially financed by the Dean's grant No. 504/03693/1110/42.000100 - "Identification and characteristics of the odour sources in biogas plants processing municipal waste".

\section{References}

1. B. Scaglia B, V. Orzi, A. Artola, X. Font, E. Davoli, A. Sanchez and F. Adani Bioresource Technology Odours and volatile organic compounds emitted from municipal solid waste at different stage of decomposition and relationship with biological stability. Bioresource Technology, 102 (7), 4638-4645 (2011) DOI: 10.1016/j.biortech.2011.01.016

2. L. De Baare, B. Mattheeuws, Anaerobic Digestion of the Organic Fraction of Municipal Solid Waste in Europe - Status, Experience and Prospects, RR, vol. 3, 517 $526(2013)$

http://www.ows.be/wp-content/uploads/2013/02/Anaerobic-digestion-of-the-organicfraction-of-MSW-in-Europe.pdf

3. Polish Standard PN-EN 13725:2007, Air Quality. Determination of odour concentration by means of the dynamic olphactometry method (in Polish) (2007)

4. M. Wiśniewska, K. Lelicińska-Serafin, The effectiveness of the mechanical treatment of municipal waste using the example of a selected installation, INFRAEKO, 45, 00102 (2018)

5. Decision of the European Parliament of the Council No. 1386/2013/EU of 20 November 2013 on the general EU programme of action in the scope of environmental protection by 2020. Good quality of life with consideration of limitations of our planet, EU Journal of Laws No. 354/171 (2013)

6. Act of 20 February 2015 on renewable energy sources, consolidated text, Journal of Laws of 2018, item 1269, with further amendments (2018)

7. https://maps.google.com/

8. Marshall of Lubelskie Voivodeship, Decision No. RŚ-V.7222.6.2015.MCHW for the Waste Management Plant in Biała Podlaska (2016)

9. Marshall of Lubelskie Voivodeship, Decision No. RŚ-V.7222.2.2016.ILU for the Waste Management Plant in Wólka Rokicka (2016)

10. Marshall of Podkarpackie Voivodeship, Decision No. OS.I.7222.52.35.2017.MD for the Waste Management Plant in Stalowa Wola (2016)

11. Marshall of Świętokrzyskie Voivodeship, Decision No. OWŚ-VII.7222.9.2016 for the Waste Management Plant in Promnik (2016) 
12. Marshall of Wielkopolskie Voivodeship, Decision No. DSR-II-2.7222.72.2016 for the Waste Management Plant in Jarocin (2016)

13. Marshall of Śląskie Voivodeship, Decision No. OS-PZ.7222.00072.2016 for the Waste Management Plant in Tychy (2016)

14. V. Orzi, E. Cadena, G. D'Imporzano, A. Artola, E. Davoli, M. Crivelli, F. Adani, Potential odour emission measurement in organic fraction of municipal solid waste during anaerobic digestion: Relationship with process and biological stability parameters, BT 101, 7330-7337 (2010)

15. J. A. Amoor, E. Hautala, Odour as an Aid to Chemical Safety, JAT, 3, 272-290 (1983).

16. J. Kośmider, B. Mazur-Chrzanowska, B. Wyszyński, Odory, Wydawnictwo Naukowe PWN (2012)

17. EUI-CHAN J., HYUN-Keun S. JAE-HWAN S., Emission Characteristics and Factors of Selected Odorous Compounds at a Wastewater Treatment Plant, Sensors, vol. 9, 311-326 (2009)

18. Regulation of the Minister of the Environment of 29 December 2016 on the detailed way of selective collection of selected waste fractions, Journal of Laws of 2017, item 19 (2017) 